\title{
Väärtuskasvatust toetavad tegevused ja nende enesehinnanguline tulemuslikkus Eesti üldhariduskoolide näitel
}

\author{
Mari-Liisa Parder ${ }^{\mathrm{a} 1}$, Helen Hirsnik ${ }^{\mathrm{a}}$ \\ ${ }^{a}$ Tartu Ülikooli eetikakeskus
}

\begin{abstract}
Annotatsioon
Siinse uurimuse eesmärk on analüüsida väärtuskasvatust toetavaid tegevusi ja nende tulemuslikkuse hindamist Eesti üldhariduskoolides. Uurime, kuivõrd toovad Eesti üldhariduskoolid refleksiooni kaudu välja väärtusi toetavaid tegevusi ning analüüsivad deklareeritud ja tegevustes rakendatavate väärtuste kooskõla. Vaatluse all on tegevused, mida koolid seostavad väärtuskasvatuse toetamisega, ning see, kas ja milliste meetoditega analüüsivad koolid väärtuskasvatust toetavate tegevuste tulemuslikkust. Analüüsi aluseks on üldhariduskoolide koostatud eneseanalüüsid, mis on esitatud Tartu Ülikooli eetikakeskuse tunnustusprogrammi ja mis sisaldavad väärtusarenduse analüüsi neljas valdkonnas. Valimisse kuulub 39 eneseanalüüsi aastatest 2010; 2016 ja 2019, mida analüüsiti kvalitatiivse sisuanalüüsi abil. Siinse uurimuse põhjal saab öelda, et Eesti koolides on levinud integreeriv eetiline kasvatus.
\end{abstract}

Võtmesõnad: väärtuskasvatus, väärtusselitus, hariduse eesmärgid

\section{Sissejuhatus: hariduse eesmärk ja väärtuste roll hariduses}

Mõtestamaks väärtuste rolli hariduses, on esmalt vaja küsida, mis eesmärki haridus täidab. Harry Brighouse (2006) toob välja neli teooriat, mis käsitlevad hariduse eesmärke. Inimautonoomia teooria kohaselt on hariduse eesmärk inimese vabadus, valikud ja õigus iseotsustamisele. Inimkapitali teooria seab hariduse eesmärgiks majanduskasvu tagamise: mida haritum on tööjõud, seda suurem on produktiivsus. Inimarengu teooria seab hariduse eesmärgiks luua tingimused heaks eluks ja isiksuse arenguks. Kodanikuteooria (ingl civic education) väidab, et hariduse eesmärk on valmistada indiviid ette ühiskonnas teistega koos elamiseks. Brighouse ise (2006) peab hariduse eesmärgiks õpilaste elukestvat õitsengut.

Haridus ja õppeprotsess on mitme teadlase (nt Haydon, 2006; Sutrop, 2015) arvates igal juhul väärtustest laetud. Väärtusi kannavad nii see, mida

Tartu Ülikooli eetikakeskus, Jakobi 2-329, 51014 Tartu; mari-liisa.parder@ut.ee. 
õppeprotsessis tehakse, kui ka see, mis seal tegemata jäetakse. Seetõttu ei ole hariduse keskne küsimus mitte, kas koolid kannavad teatud väärtusi edasi, vaid hoopis, kuivõrd teadlikud avalduvatest väärtustest ollakse, kui teadlikult väärtuskasvatust ellu viiakse ning kus ja kuidas elatud väärtused avalduvad. Väärtuskasvatus on protsess, mis sisaldab enda ja teiste väärtuste mõistmist, väärtuste üle mõtlemist ja arutlemist, väärtuste praktiseerimiseks vajalike tingimuste loomist ning väärtuste tagasisidestamist.

Artiklis vaatleme, kuivõrd toovad Eesti üldhariduskoolid refleksiooni kaudu välja väärtusi toetavaid tegevusi ning analüüsivad deklareeritud ja tegevustes rakendatavate väärtuste kooskõla. Analüüsime, milliseid tegevusi seostavad koolid väärtuskasvatuse toetamisega ning kas ja milliste meetoditega koolid väärtuskasvatust toetavate tegevuste tulemuslikkust hindavad.

\section{Väärtuskasvatuslikke lähenemisi}

Väärtuskasvatuslikest lähenemistest saab välja tuua kolm peamist suunda: ratsionalistlik kõlbluskasvatus, iseloomukasvatus ning integreeriv eetiline kasvatus.

Ratsionalistlik kõlbluskasvatus keskendub reflekteerivale arutlemisele ning autonoomse moraalse tegutseja kasvatamisele. Lähenemine lähtub universalistlikust reeglieetikast (nt Kohlberg, 1981; Power, Higgins, \& Kohlberg, 1989), ning selle aluseks on Kanti deontoloogiline eetika, mille järgi on võimalik mõistuse abiga välja töötada absoluutne ehk mitteüleskaalutav moraaliprintsiipide kogum (Pojman, 2005, lk 221), mis tähendab, et moraalne on käitumine, mis on kooskõlas konkreetses olukorras rakenduvate printsiipidega (Narvaez, 2006). Ratsionalistlik kõlbluskasvatus arvestab Piaget' moraalse arengu astmete teooria ja laste kognitiivse arenguga (Narvaez, 2006).

Ratsionalistlikule kõlbluskasvatusele on ette heidetud, et tal puudub konkreetne sisu ning ta annab lastele liiga palju võimu, lubades arutleda asjade üle, mille üle ei peaks arutlema (nt karistuse määramine reeglite rikkumisel) (Narvaez, 2006).

Ratsionalistliku kõlbluskasvatuse üks meetodeid on olnud väärtusselitus (ingl values clarification) (Kirschenbaum, 1977), mille üle debateeriti 1970.1980. aastatel ning mille keskmes on eeldus, et väärtused ja väärtustamine on sügavalt isiklikud, mistõttu ei ole võimalik väärtusselituse kaudu edasi anda konkreetseid väärtusi (Volkmor, Pasanella, \& Raths, 1977, lk 47). Lisaks ei ole olemas üht lõplikku väärtuste kogumit, mille suhtes oleks saavutatud kokkulepe (Raths, Harmin, \& Simon, 1978). Seetõttu on väärtusselituse toetajad vastu kahele asjale: ühelt poolt kokku leppimata väärtuste juurutamisele ja teiselt 
poolt indiviidi allutamisele grupiväärtustele (Chazan, 1985). Väärtusselituse toetajad rõhutavad, et kuigi nad ei saa anda lastele absoluutseid väärtusi, annavad nad midagi paremat: süsteemi ja meetodid, kuidas ise enda väärtusteni jõuda (Simon ja Olds, 1976, lk 17).

Rokeach $(1975,1979)$ peab väärtusselitust moraalse ja sotsiaalse konteksti suhtes naiivseks, sest väärtustamisprotsess ei toimu vaakumis. Samuti on tema sõnul eksitav väide, et väärtuste selitamise metoodika ise on väärtusvaba veelgi enam, ta heidab ette, et õpilastele hiilitakse teatud väärtuskompleksiga salaja ligi (Rokeach, 1975, lk 123). Ka Chazan (1985) nendib, et väärtuste selitamine lähtub humanistlikest värrtustest: avatus, teiste eest hoolitsemine, eneseteadlikkus ja tähelepanelikkus. Väärtuste selitamise isaks peetud Kirschenbaum (1977) vastab kriitikale, rõhutades, et väärtuste selitamine ei ole kunagi olnud väärtusvaba. Ta toob välja, et metoodika ei ole egoistlik ega väljenda hedonistlikku huvipuudust teiste inimeste väärtuste suhtes, vastupidi, „[s]elitamise protsessi keskmes on alati olnud mure enese arvamuse (nii isiklike kui sotsiaalsete) tagajärgede pärast“ (Kirschenbaum, 2009, lk 126). Asjaolu, et väärtuste selitamine toetub juba olemasolevale isiklikule väärtusbaasile (ehk pole väärtusvaba), on Kirschenbaum välja toonud mitmes oma hilisemas kirjutises (nt Kirschenbaum, 2013).

Teine väärtuskasvatuslik lähenemine - iseloomukasvatus - keskendub selliste tingimuste loomisele hariduses, mis aitavad vooruslikel iseloomujoontel kujuneda ja kinnistuda, ning selle taust on Aristotelese vooruseetika (mistõttu räägitakse selles lähenemises voorustest) (Põder, Sutrop, \& Valk, 2009, lk 8). Koolides avaldub iseloomukasvatus näiteks sõnade või mõistete kogumite ümber (nt kooli eetiline kava, kuu märksõnad), mida kool on määratlenud iseloomutunnustena ning mis on kooli missioonis keskne (Berkowitz, 2002). Berkowitz (2009, lk 198) defineerib iseloomu kui „indiviidi psühholoogiliste omaduste kogumit, mis mõjutab selle inimese võimet ja kalduvust moraalselt toimida“.

Berkowitz (2002) toob välja seitse asja, mis iseloomukasvatuse puhul koolis töötavad: 1) kuidas inimesed last kohtlevad; 2) kuidas lapsele olulised inimesed kohtlevad tema juuresolekul teisi; 3) hea iseloomu ootamine kõikidelt oma liikmetelt; 4) positiivse iseloomu toetamine; 5) võimalused hea iseloomu harjutamiseks; 6) võimalused moraalsete teemade üle vaielda, mõtiskleda ja neid põhjendada; 7) et vanemad oleksid aktiivselt ja positiivselt kooli iseloomukasvatuse tegevustesse kaasatud.

Narvaez (2006) pakub välja kolmanda võimaluse - integreeriva eetilise kasvatuse -, mis ühendab ratsionalistliku kõlbluskasvatuse ning iseloomukasvatuse. Selle lähenemise puhul peetakse oluliseks reflekteeriva arutlusvõime arendamist kombineerituna selliste iseloomujoonte kujundamisega, 
mida ühiskonnaliikmed vajavad demokraatliku pluralistliku ühiskonna ja selle institutsioonide toimimiseks. Gutman (1987) rõhutab, et kuigi laste moraalse arengu eest on esmavastutus perekonnal, on demokraatlikul riigil huvi kodanikkonna moraalse kujunemise vastu - moraalikasvatus demokraatlikus riigis on vastastikku kasulik usalduse jagamine perekonna ja riigi vahel. Vähetähtsaks ei tohiks selles kontekstis pidada ka väärtuskasvatuse eesmärki õppida mineviku vigadest tänapäeva moraalsete inimeste kasvatamisel (Bergdahl \& Langmann, 2018).

\section{Koolide roll väärtuskasvatuse toetamisel}

Graham Haydon (2006) küsib provokatiivselt, kas väärtuste ja vooruste kujundamisega peaksid tegelema õpetajad ja koolid. Väärtuste edastamisega seoses toob ta välja probleeme, mis pole seotud niivõrd väärtuste endiga, kuivõrd nende edastamisega. Esiteks küsib ta, mida saab üldse pidada väärtuste edastamiseks, teiseks märgib, et edastatava sisu võib olla ebaühtlane, ning kolmandaks rõhutab, et kui ühiskonnas on vastukäivad väärtused, ei saa neid väärtusi tervikuna edastada. Lisaks ei ole väärtused selgepiirilised. Küll aga jõuab ka tema tõdemuseni, et pluralistlikus ühiskonnas ei ole oluline mitte üksnes väärtusi omandada, vaid ka enda ja teiste väärtusi mõista. Seetõttu vastab ta ise oma provokatiivsele küsimusele - teiste väärtuste mõistmist saab mõjutada just kohustusliku koolihariduse kaudu. (Haydon, 2006)

Eestis on sarnaseid mõtteid - et väärtusvaba haridus on müüt - väljendanud Margit Sutrop (2015). 1970ndatel maailmas rakendunud hariduslähenemisega asuti propageerima väärtusvaba haridust ning seati õppeprotsessi keskmesse teadmiste omandamine. Nii ignoreeriti Sutropi sõnul seda, et haridusprotsess on oma olemuselt värrtustest laetud ning sellel on sügav eetiline dimensioon, sest põhineb arusaamal, milline inimene on ja kuidas ta elama peaks. Hariduse humanistliku arusaama järgi, mille eestkõneleja oli Wilhelm von Humboldt, on haritud inimene keegi, kes püüab ümbritsevat maailma mõista ja sellega tihedat kontakti luua (Sutrop, 2015, lk 190).

Väärtuskasvatuses on võtmeroll õpetajal, kes ei pea olema ideaalne inimene, kuid peab tundma moraalse arengu ning inimeste käitumise psühholoogilisi aspekte ning klassiruumi juhtimise meetodeid. Õpetaja peaks oskama märgata koolikultuuris avalduvaid väärtusi ning lõhesid elatud ja deklareeritud väärtuste vahel, mida ta peaks suutma analüüsida sotsiaalteaduslike meetoditega (mh vaatlus ja intervjuud). (Sutrop, 2015, lk 195) Nimetatud meetodite tundmine võimaldab toetada õpetaja märkamiskompetentsi näiteks dokumentide ja hindamisjuhiste lugemisel (nt diskursusanalüüs), aga ka õpilaste arusaamade kuulamisel (nt intervjueerimistehnikad). 
Mitmest empiirilisest uuringust selgub, et koolid ei pea valima, kas tegeleda väärtuskasvatusega või keskenduda teadmistele, sest väärtuskasvatusel on õpitulemustele positiivne mõju. Berkowitz ja Bier (2009, lk 295-298) jaotavad empiirilised uuringud koondülevaate jaoks neljaks: koolieelne haridus, algkool, põhikool ning keskkool. Koolieelses hariduses osalevate ühe- kuni nelja-aastaste laste sotsiaalse arengu heaks indikaatoriks olid õpetaja-lapse suhted - õpetajaga turvalise kiindumussuhtega õpilased olid rõõmsamad ja positiivsemad ning osalesid keerukamates sotsiaalsetes mängudes (Howes, Matheson, \& Hamilton, 1994). Ka Howes ja Smith (1995) leidsid, et positiivne suhtlus õpetajaga ja kiindumus aitasid prognoosida laste kognitiivset tegevust.

Algkooli puhul on otsene seos iseloomukasvatuse efektiivsuse ja selle vahel, kui hooliva kogukonnana ópilased oma klassi ja kooli tajuvad (Solomon, Watson, \& Battistich, 2001). Solomon jt (1996) leidsid, et koostööstrateegiate ja sotsiaalsete väärtuste rõhutamine õpetajate poolt on seotud sellega, mil määral õpilased tajuvad klassi kogukonnana.

Põhikooli uuringud keskenduvad peamiselt õpetaja-õpilase suhetele. Uurimistulemused näitavad, et vastastikku austav suhtlus suurendab akadeemilist tulemuslikkust ja suutlikkust ennast kontrollida (Ryan \& Patrick, 2001). Wentzel (2002) leidis omakorda, et iseloomukasvatust ja akadeemilisi saavutusi edendavad õpetajad esitavad õpilastele kõrgemaid nõudmisi, on toetavad ega anna negatiivset tagasisidet, kasutavad demokraatlikku suhtlemist ja on õiglased, motiveerivad õppimist ning ei kehtesta käitumisele palju reegleid.

Keskkooli puhul on vaadeldud iseloomukasvatuse ja riskikäitumise seoseid. Resnick jt (1997) tõid välja, et riskikäitumisele oli olemas kaks kaitsefaktorit: kiindumus perekonda ja kiindumus kooli. Sama andmestiku pealt järeldasid McNeely jt (2002) ning Bonny jt (2000), et sidet kooliga toetasid järgmised elemendid: 1) positiivne klassijuhtimine; 2) mõistvad distsiplineerivad praktikad; 3) kaasatus koolivälistesse tegevustesse; 4) väiksemad koolid; 5) hea füüsiline tervis ja 6) suitsetamisest hoidumine.

Seda, et koostööl põhinev klassikliima toetab akadeemilisi saavutusi, leidsid ka Wang jt (1993). Suyatno jt (2019) leidsid, et õpetajate refleksioon oma uskumuste ja väärtuste üle mõjutab nende käitumist klassiruumis ning nad suudavad oma erialaseid ülesandeid paremini täita. Viimased uuringud näitavad samuti seoseid väärtuskasvatuse ja õpitulemuste vahel. Jeynes (2019) tegi metaanalüüsi, et uurida iseloomukasvatuse ja õpitulemuste seost. Valimisse kaasatud 52 uuringut tõid välja, et iseloomukasvatus on seotud paremate õpitulemustega (Jeynes, 2019). 


\section{Väärtuskasvatus Eesti hariduses}

Väärtuste rolli Eesti hariduses on viimasel kümnendil järjest rohkem tähtsustatud. Temaatika tõsteti Eesti hariduselus tugevalt esile alates 2009. aastast, kui Haridus- ja Teadusministeerium kinnitas riikliku väärtusprogrammi („Eesti ühiskonna väärtusarendus 2009-2013“). 2010. aastal vastu võetud põhikooli- ja gümnaasiumiseadus sõnastas muu hulgas üldhariduskooli alusväärtused ( $\$ 3$ ) ning tõi põhikooli $(\$ 4)$ ja gümnaasiumi $(\$ 5)$ ülesandena välja nii hariva kui ka kasvatava ülesande, rõhutades gümnaasiumi ülesandes sõnaliselt ka väärtushoiakute kujunemise olulisuse.

Hariduse üks eesmärke on tuleviku väljakutsetega toimetulek ning seetõttu õpilaste ettevalmistus tuleviku eluks. Sutrop (2015, lk 193) toob siin välja hariduse paradoksi - õpetajad, kes omandasid oma väärtused eile, peavad tänastele õpilastele kaasa andma väärtuste pagasi, millega nad homme ellu astuvad. Ka Fadel jt $(2015,1 \mathrm{k} 1)$ rõhutavad, et haridus peab õpilasi ette valmistama järjest kiiremate majanduslike ja sotsiaalsete muutustega toimetulekuks, ametiteks, mida ei ole veel loodud, tehnoloogia kasutamiseks, mida pole veel leiutatud, ning sotsiaalsete murede lahendamiseks, mida me veel ei tea tekkivat.

Ka haridusvisioon aastaks 2035 (Sutrop, Lauristin, Loogma, \& Eamets, 2019) pöörab eraldi tähelepanu nii tuleviku väljakutsetele kui ka väärtustele ja väärtuskasvatusele, tuues välja Eesti ühiskonna põhinemise humanistlikel väärtustel. Visioon rõhutab aga eraldi, et „... ühiskonna heaolu ja demokraatliku õigusriigi püsimiseks on oluline toetada dialoogi ja refleksiooni ühiste värrtuste üle ning edendada kriitilist mõtlemist ja vastutustundlikku suhtumist ühiskonda" (Sutrop jt, 2019, lk 15).

Varasem Eesti haridusstrateegia (Aarna jt, 2011) tõi välja hariduse isiksusliku, kultuurilise ja ühiskondliku väärtuse. Hariduse keskmes nähti õppija individuaalsust ja mitmesuguste kompetentside (kriitiline mõtlemine, sotsiaalsed oskused, loovus, ettevõtlikkus jne) arendamist ning õpetaja roll selles on olla protsessi suunaja ja toetaja. Lisaks on riikliku õppekava üks läbivaid teemasid „Väärtused ja kõlblus“: „taotletakse õpilase kujunemist kõlbeliselt arenenud inimeseks, kes tunneb ühiskonnas üldtunnustatud väärtusi ja kõlbluspõhimõtteid, järgib neid koolis ja väljaspool kooli, ei jää ükskõikseks, kui neid eiratakse, ning sekkub vajaduse korral oma võimaluste piires“ (Põhikooli riiklik õppekava, 2011). Küll aga ei ole sellesisulised muudatused jõustunud ainekavade tasemel, samuti sõltub väärtuspõhisele koolile üleminek sellest, milline on õpetajate väärtuskasvatuslik pädevus, kasutatav õppevara ning milliseid võimalusi annab koolikultuur (Sutrop jt, 2019). Seda ilmestab ka inimõiguste haridus, millel on oluline roll demokraatliku riigi kestlikkuses, kuid mis ei ole veel kõigisse ainevaldkondadesse lõimitud, mistõttu on oht, et inimõiguste hariduse käsitlus muutub vaid sotsiaalainetekeskseks (Käger et al., 2017). 
Tartu Ülikooli eetikakeskus on riiklikus väärtusprogrammis („Eesti ühiskonna väärtusarendus 2009-2013“) korraldanud konkursse (2009-2012 väärtuskasvatuse konkursi nime all, alates 2012 hea kooli konkursi nime all), et suunata koole mõtestama värrtuskasvatusalaseid tegevusi, neid eesmärgistama, ellu viima ja tulemuslikkust hindama ning häid näiteid üles täheldama. Eneseanalüüside koostamise aluseks on hea kooli mudel, mille Tartu Ülikooli eetikakeskus töötas välja 2013. aastal koos 87 haridusvaldkonna eksperdiga (Sutrop, 2017). Konkursi eesmärk on arendada koolide väärtusarenduslikku pädevust ja tõenduspõhise eneseanalüüsi võimekust, toetada koole teadlike valikute tegemisel ja arendustegevuste planeerimisel, koguda ja levitada häid näiteid ning tunnustada koole (Hea kooli ja hea lasteaia tunnustamine, 2020). Konkursile esitatud eneseanalüüsid saavad kirjalikku tagasisidet, võimalus on saada tagasisidet ka vahetu kohtumise käigus (ibid.).

Artiklis vaatleme, kuivõrd oskavad Eesti koolid läbi eneserefleksiooni välja tuua väärtusi toetavaid tegevusi ning analüüsida deklareeritud ja tegevustes rakendatavate väärtuste kooskõla. Vaatluse all on tegevused, mida Eesti üldhariduskoolid seostavad väärtuskasvatuse toetamisega, ning see, kas ja milliste meetoditega analüüsivad koolid värrtuskasvatust toetavate tegevuste tulemuslikkust.

\section{Metoodika}

\section{Valim}

Valimi moodustasid 39 eneseanalüüsi, mille koolid on aastate jooksul Tartu Ülikooli eetikakeskuse konkursile esitanud ning mis olid uurijatele kättesaadavad. Konkursil on alates 2009. aastast oodatud osalema koolid üle Eesti ning sellekohast infot on nad saanud nii personaalse osalemiskutsena meilile kui ka koolidele ja lasteaedadele suunatud infokanalitest. Konkursile esitatud eneseanalüüsid sisaldavad värrtusarenduse analüüsi neljas valdkonnas: õppeja kasvatustöö, koolikeskkond, juhtimine, koostöö ja head suhted. Valisime analüüsiks eneseanalüüsid aastatest 2010; 2016 ja 2019. Kuigi konkurss on toimunud alates 2009. aastast, ei võetud valimisse esimese, prooviaasta töid. 2010. aasta eneseanalüüsid on kirjutatud vabas vormis ja seosed nelja valdkonnaga on leitavad kaudselt. 2016. aasta valiti, sest need analüüsid valmisid eelnevatel aastatel uuenenud ja katsetatud vormis. 2016. ja 2019. aasta eneseanalüüsid on koostatud soovitusliku vormi alusel neljas valdkonnas (õppe- ja kasvatustöö; koolikeskkond; juhtimine; koostöö ja head suhted), toetudes Tartu Ülikooli eetikakeskuse välja töötatud hea kooli mudeli aspektidele (Sutrop ja Harro-Loit, 2013). Uurimuse valim on eesmärgipärane mugavusvalim, kus 
valimisse kuulunud eneseanalüüsid olid uurijatele kättesaadavad (Laherand, 2008; Õunapuu, 2014).

Valimi moodustanud eneseanalüüsid varustati enne kodeerimist pseudonüümidega. Kodeerimisel markeeriti eneseanalüüsi kirjutamise aasta (2010; 2016 või 2019). Seejärel markeeriti kooli suurus lähtuvalt õpilaste arvust analüüsi koostamise ajal (andmete allikas haridussilm.ee). Valimisse kuulunud koolide keskmine õpilaste arv oli 352 ja sellest lähtuvalt nimetati alla 350 õpilasega koolid väikesteks ning üle 350 õpilasega koolid suurteks. Viimasena markeeriti kooli asukoht: linna- ja maakoolid. Sarnaste koodidega koolid on eristatud järjekorranumbrite alusel. Näiteks: 2019 suur linnakool 1; 2019 suur linnakool 2. Need koolid, kes on eneseanalüüse kirjutanud kahel korral, on eristatud järjekorranumbri asemel alfabeetiliselt, näiteks 2010 suur linnakool A ja 2016 suur linnakool A, mis tähistavad ühe ja sama kooli eneseanalüüsi eri aastatel. Tulemuste esitamisel viidatakse koolile nimetatud koodiga.

Tabel 1. Eneseanalüüsid koostanud koolide valim

\begin{tabular}{|c|c|c|c|c|c|}
\hline \multirow{2}{*}{$\begin{array}{l}\text { Kirjutamise } \\
\text { aasta }\end{array}$} & 2010 & \multicolumn{2}{|c|}{2016} & \multicolumn{2}{|c|}{2019} \\
\hline & $\begin{array}{l}\text { 1. } 2010-\text { suur } \\
\text { linnakool A }\end{array}$ & $\begin{array}{l}\text { 7. } 2016 \text { - väike } \\
\text { linnakool } 1\end{array}$ & $\begin{array}{c}\text { 16. } 2016 \text { - väike } \\
\text { maakool } 1\end{array}$ & $\begin{array}{l}\text { 23. } 2019 \text { - väike } \\
\text { linnakool } 1\end{array}$ & $\begin{array}{c}\text { 32. } 2019 \text { - väike } \\
\text { maakool } 3\end{array}$ \\
\hline & $\begin{array}{l}\text { 2. } 2010 \text { - suur } \\
\text { linnakool }\end{array}$ & $\begin{array}{l}\text { 8. } 2016 \text { - väike } \\
\text { linnakool } 2\end{array}$ & $\begin{array}{c}\text { 17. } 2016 \text { - väike } \\
\text { maakool } 2\end{array}$ & $\begin{array}{l}\text { 24. } 2019 \text { - väike } \\
\text { linnakool } 2\end{array}$ & $\begin{array}{c}\text { 33. } 2019 \text { - väike } \\
\text { maakool } 4\end{array}$ \\
\hline & $\begin{array}{l}\text { 3. } 2010 \text { - väike } \\
\text { maakool } 1\end{array}$ & $\begin{array}{l}\text { 9. } 2016 \text { - väike } \\
\text { linnakool } 3\end{array}$ & $\begin{array}{c}\text { 18. } 2016 \text { - väike } \\
\text { maakool } 3\end{array}$ & $\begin{array}{c}\text { 25. } 2019 \text { - väike } \\
\text { linnakool } 3\end{array}$ & $\begin{array}{c}\text { 34. } 2019 \text { - väike } \\
\text { maakool } 5\end{array}$ \\
\hline & $\begin{array}{l}\text { 4. } 2010 \text { - väike } \\
\text { maakool } 2\end{array}$ & $\begin{array}{c}\text { 10. } 2016 \text { - väike } \\
\text { linnakool } 4\end{array}$ & $\begin{array}{c}\text { 19. } 2016 \text { - väike } \\
\text { maakool } 4\end{array}$ & $\begin{array}{l}\text { 26. } 2019 \text { - suur } \\
\text { linnakool B }\end{array}$ & $\begin{array}{c}\text { 35. } 2019 \text { - väike } \\
\text { maakool } 6\end{array}$ \\
\hline \multirow[t]{5}{*}{ KOOD } & $\begin{array}{l}\text { 5. } 2010 \text { - väike } \\
\text { maakool } 3\end{array}$ & $\begin{array}{c}\text { 11. } 2016 \text { - suur } \\
\text { linnakool A }\end{array}$ & $\begin{array}{c}20.2016 \text { - suur } \\
\text { maakool D }\end{array}$ & $\begin{array}{c}\text { 27. } 2019 \text { - suur } \\
\text { linnakool } 1\end{array}$ & $\begin{array}{c}\text { 36. } 2019 \text { - väike } \\
\text { maakool } 7\end{array}$ \\
\hline & $\begin{array}{l}\text { 6. } 2010-\text { suur } \\
\text { maakool }\end{array}$ & $\begin{array}{c}\text { 12. } 2016 \text { - suur } \\
\text { linnakool B }\end{array}$ & $\begin{array}{c}21.2016 \text { - suur } \\
\text { maakool } 1\end{array}$ & $\begin{array}{l}\text { 28. } 2019 \text { - suur } \\
\text { linnakool } 2\end{array}$ & $\begin{array}{c}\text { 37. } 2019 \text { - suur } \\
\text { maakool D }\end{array}$ \\
\hline & & $\begin{array}{l}\text { 13. } 2016 \text { - suur } \\
\text { linnakool } 1\end{array}$ & $\begin{array}{c}22.2016 \text { - suur } \\
\text { maakool } 2\end{array}$ & $\begin{array}{l}\text { 29. } 2019 \text { - väike } \\
\text { maakool C }\end{array}$ & $\begin{array}{c}\text { 38. } 2019 \text { - suur } \\
\text { maakool } 1\end{array}$ \\
\hline & & $\begin{array}{c}\text { 14. } 2016 \text { - suur } \\
\text { linnakool } 2\end{array}$ & & $\begin{array}{c}\text { 30. } 2019 \text {-väike } \\
\text { maakool } 1\end{array}$ & $\begin{array}{c}\text { 39. } 2019 \text { - suur } \\
\text { maakool } 2\end{array}$ \\
\hline & & $\begin{array}{c}\text { 15. } 2016 \text { - väike } \\
\text { maakool C }\end{array}$ & & $\begin{array}{c}\text { 31. } 2019 \text { - väike } \\
\text { maakool } 2\end{array}$ & \\
\hline
\end{tabular}




\section{Andmeanalüïs}

Et konkursitööd on esitatud tekstilises vormis, valisime andmeanalüüsiks temaatilise sisuanalüüsi, mis võimaldab uurida interpretatsioone ja hinnanguid materjalist tekkivate teemade abil (Ezzy, 2002). Sisuanalüüsiks kodeeriti tekstiline materjal esmaste teemade alla, mis loodi kirjanduse alusel, võttes keskseks tegija perspektiivi, sest väärtuskasvatuse edukus sõltub konkreetsetest tegijatest, näiteks koolijuht, õpetaja, õpilane (vt Berkowitz, 2002; Berkowitz \& Bustamante, 2013; Haydon, 2006; Simon, Howe, \& Kirschenbaum, 1978; Sutrop, 2015). Tööde kodeerimisel loodi teemasid juurde, lähtudes sellest, milliseid tegijaid koolid oma töödes nimetasid (nt lapsevanem, koolipidaja, tugipersonal), mistõttu on uurimisstrateegiana kasutatud deduktiivse ja induktiivse strateegia kombinatsiooni (Õunapuu, 2014). Kodeerisid kaks uurijat ning küsimuste tekkimisel arutasid uurijad need järjest läbi. Kodeerimisel kasutati Maxqda kvalitatiivandmete analüüsiprogrammi.

Kodeerimise tulemusena moodustus 1924 kirjet, mis jagunesid kümne teema alla: üks teema väärtuskasvatust toetavate tegevuste tulemuslikkuse analüüsi kohta, seitse tegija perspektiivist lähtuvat teemat (koolipidaja, juhi, õpetaja, õpilase, tugispetsialisti, muu personali ja lapsevanema perspektiiv) ning kaks laiemat teemat (kogukond ja organisatsioon). Kuna siinse uurimuse keskmes on reaalselt ellu viidavad tegevused, jäid analüüsist kõrvale kaks teemat - kogukond ja organisatsioon - sest nendes sõnastatakse üldisi tegevusi või põhimõtteid, mida ei ole seostatud konkreetse tegijaga. Samuti jäid kõrvale tegevused, mille tegemist koolid alles plaanivad (nt arendusvõimalused, kitsaskohtadega tegelemise plaanid). Analüüsitud on töödes sisalduvaid näiteid, mis vastavad küsimusele, kuidas kirjeldatud väärtuskasvatusalaseid tegevusi ellu viiakse.

Analüüsi tulemusel eristusid tegija perspektiivist selgelt kaks: õpetaja (240 kirjet) ja õpilane (196 kirjet), mistõttu keskendub analüüs neile kahele tegijale. Õpilase teemasse paigutusid tegevused, milles õpilane on aktiivsem pool. Näiteks klassis toimuv arutelu paigutus õpilase teema alla, kui seda oli kirjeldatud ning analüüsitud pigem õpilase tegevusest ning aktiivsusest lähtuvalt, ning õpetaja teema alla, kui seda oli kirjeldatud ja analüüsitud pigem õpetaja vaatenurgast.

Nii andmekogumine, valim kui ka andmeanalüüsi meetod seavad järelduste tegemisele piirangud. Esiteks on oma töö konkursile esitanud koolid, kes on väärtuskasvatust tähtsustanud ning peavad oluliseks väärtustega tegelemist ja oma tegevuste analüüsimist. Teiseks lähtuvad koolid oma analüüsides suuresti Tartu Ülikooli eetikakeskuse pakutud raamistikest (Harro-Loit jt, 2011; Sutrop, 2013; Sutrop, Toming, \& Kõnnussaar, 2017), kuid koolid on siiski ise 
otsustanud, milliseid tegevusi nad väärtuskasvatuse näidetena esitlevad ja analüüsivad ning seega on eneseanalüüside aluseks valik juba tehtud. Kolmandaks kuulub valimisse vaid 39 kooli, kes on ise otsustanud konkursil osaleda, mistõttu ei ole valim ega sellest lähtuvad tulemused üldistatavad kõigile koolidele Eestis. Sellegipoolest annab materjal ülevaate sellest, kuidas osalenud koolid ise värrtuskasvatust ja sellega seotud tegevusi mõtestavad ja seostavad ning milliseid tegevusi nad koolis ellu viivad.

\section{Tulemused}

\section{Õpetaja kui väärtuskasvatuse võtmeisik}

Tulemused näitavad, et õpetajad teevad väga palju mitmesuguseid tegevusi, mis koolide seisukohalt väärtuskasvatust toetavad ning mis kirjanduse järgi kuuluvad integreeriva eetilise kasvatuse alla. Eristuvad tegevused, mis toetavad väärtuskasvatust otseselt (nt eri formaatides väärtusarutelud õpilastega), kuuludes ratsionalistliku kõlbluskasvatuse alla, ning tegevused, mis toetavad väärtuskasvatust kaudselt, koolikultuuri kujundamise kaudu (mitmesuguste dokumentide, sh kooli kodukorra analüüsimine ja parendamine), mis kuuluvad iseloomukasvatuse alla.

Eneseanalüüside kirjutajad peavad oluliseks õpetajate kaasamist juhtimisprotsessidesse ehk kooli arengu seisukohast oluliste otsuste tegemisse. Õpetajaid kaasatakse näiteks arenguvestluste, eneseanalüüsi ning õpetajatele mõeldud rahuloluküsitluste kaudu. Sellised tegevused on juhi poolt suunatud ja enamasti seotud arengukava loomisega ning õpetajatele on ülesanne juhi poolt ette antud. Õpetajad osalevad ka väärtuste mõtestamises:

Peale põhiväärtuste sõnastamist oli óppetoolide ülesandeks väärtused lahti sõnastada, kuidas õpetajad neid väärtusi mõistavad. (2010 suur linnakool)

Õpetajatepoolsed algatused on juhtimisprotsessides pigem erandlikud ja eneseanalüüside põhjal saab öelda, et juhi ülesanne on motiveerida õpetajaid juhtimisprotsessides osalema.

Arendustegevustes osaletakse ka töögruppide kaudu, enamasti konkreetsete ette antud ülesannete või probleemide varal:

Töögruppide teemad: kooli dokumentatsioon, informatsiooni liikumine ja kommunikatsioon, suhtlemine õpetajate vahel, ópetajate toetamine, õpilaste toetamine, akadeemiline suhtlemine, ópilaste tugisüsteemid. (2016 suur linnakool 2) 
Töögrupid tegelevad ka sihipäraselt kooli väärtusarendusega, jälgides ja analüüsides näiteks väärtuste ilmnemist koolielus (ainetundides, üritustes ja dokumentides). Töögruppide puhul on ülesande püstitus olnud juhtkonna poolt ette antud ja õpetajate läbirääkimisruum on selles väike, kuid ülesande lahendamise juures näib seda olevat rohkem.

Olulisele kohale on koolid seadnud ka õpetajatevahelise koostöö. Esiteks näevad koolid sellest õppetöö efektiivsuse tõusu (ained on omavahel lõimitud, seosed igapäevaeluga selgemad). Teiseks soodustab see omavahelist teadmiste ning kogemuste vahetamist ja heade näidetega tutvumist:

Üha enam tuuakse tundi teadlikku ainetevahelist lõimingut, mis pakub paremaid võimalusi projektõppeks. Seda soodustab kindlasti ka õpetajate vaheline hea koostöö - paralleelklasside õpetajad planeerivad ühiselt nii óppetööd kui ka kirjutavad ühiselt projekte [...] (2016 väike linnakool 1)

Kolmandaks aitab õpetajatevaheline koostöö koolide sõnul ellu viia väärtuskasvatuslikke eesmärke ka läbi eeskuju. Kui õpilased näevad koostöiselt tegutsevaid õpetajaid, saavad nad väärtusliku mudeli, mille järgi koostööd õppida. Eeskuju oluliseks pidamine kõlab kokku Berkowitzi (2002) käsitlusega, mille järgi toetab eeskujude järgimine iseloomukasvatust ning on oluline, et kogu kooli personal väljendab oma käitumisega kooli jaoks olulisi väärtusi:

Kooli töötajate eeskuju on väga tähtis: näiteks vahetusjalatsid, käte pesemine enne sööki, täpsus õpetaja poolt, tundi mitte hilinemine, kokkulepete täitmine. (2019 väike linnakool 1)

Ainetundides seostavad kirjutajad väärtuskasvatusega nii erinevaid aktiivõppe meetodeid (nt suhtlemist soodustavad rühmatööd) kui ka eri programmidest pärit meetodeid (Liikuma Kutsuv Kool, Vaikuseminutid), millega tundidesse ka vaheldust tuuakse. Samuti toovad kirjutajad välja aineõpetaja poolt koordineeritud tunnivälise töö:

Aineõpetaja teeb õpilastega tundide ilmestamiseks väljasõite. (2016 suur maakool 1)

Suurem rõhuasetus on klassijuhatajate rollil väärtuskasvatuses ning seda töös klassi kui terviku ning õpilase kui indiviidiga:

Üheks näiteks on see, et meie kooli tunniplaanis on [...] klassijuhataja tund. See annab võimaluse klassijuhatajal oma ópilastega rääkida väärtus- ja enesearendusteemadel, tegeleda grupi kui tervikuga ja vajadusel viia läbi ülekoolilisi üritusi. (2016 väike maakool 2) 
Nii õpilase kui ka kogu klassiga tegelemisel viib klassijuhataja läbi väärtustel põhinevaid vestlusi. Olulisel kohal on siin arenguvestlused õpilastega (mida nähakse ka klassijuhataja ja lapsevanema kokkupuutekohana), klassijuhatajatunni olemasolu iseenesest, mitmesugustes projektides/programmides osalemine ning klassiürituste korraldamine.

Koolid rõhutavad sarnaselt teadlastega (Wang, 1993; Krek ja Zabel, 2017) refleksiooni kui väärtuskasvatuse olulist osa. Analüüsitud töödes keskenduvad õpetajate eneseanalüüsid õppeaasta eesmärkidele, isiklikule arengule ja koolitusvajadusele.

Kooli töötajad koostavad iga õppeaasta lópul eneseanalüüsi oma tööalastest õnnestumistest ja probleemkohtadest ning tulevikuplaanidest uueks öppeaastaks. (2019 väike maakool 2)

Õpetajate eneseanalüüsi peavad koolid õpetaja personaalse enesearengu üheks olulisemaks osaks. Oluliseks peetakse õpetaja eneseanalüüsi seostamist õppeaasta lõpu ja/või arenguvestlusega. Vähem on näiteid õpetajate eneseanalüüsist, mis toimub jooksvalt õppeaasta sees ning on pigem seotud konkreetsete teemadega (nt digipööre koolis).

Kirjanduse ja valimisse kuulunud koolide eneseanalüüside põhjal saab öelda, et väärtuskasvatuse võtmeisikuks peavad koolid õpetajat. Seejuures tõuseb eneseanalüüsidest esile klassijuhataja roll. Näited õpetajate tegevusest kätkevad nii iseloomukasvatuse kui ka arutlusvõime arendamise elemente, mistõttu saab öelda, et õpetajad rakendavad pigem integreerivat eetilist kasvatust (Narvaez, 2006).

\section{Õpilase roll väärtuskasvatuses}

Õpilaste puhul peavad koolid oluliseks tegevusi, mida saab liigitada ratsionalistliku kõlbluskasvatuse alla. Fookuses on väärtuste mõistmine, mõtestamine ja vastandlike väärtuste märkamine, kus ülesande seda teha annab õpetaja õpilasele ette. Näiteks on välja toodud mängulised arutelud, milles leidub ka väärtusselituse elemente, millega toetatakse õpilaste jõudmist isiklike väärtuste äratundmiseni:

4. klassi öpilased koostasid täringumängu „Hea või halb“. [...] Leppisime kokku, et kasutame mängus enam koolielu puudutavaid vastandlikke väärtusi [...] Diferentseerisime, näiteks "hooliv" saab kohe lõppu, „teen trenni“10 sammu edasi [...] „vägivaldne“ - algusesse. Hiljem mängureegleid täiendati, näiteks, kui täring satub väärtusele "hooliv“, siis mängija toob näite, kuidas see koolis või kodus on ilmnenud. (2010 väike maakool 3) 
On tähelepanuväärne, et koolid suunavad õpilasi märkama vastandlikke väärtusi ning kaaslaste teistsuguseid valikuid, võimaldades seega õpilastel näha väärtuste seost ja mõju igapäevaelu otsustele ja käitumisele. Õpetajad pööravad tähelepanu ka sellele, kuidas õpilased mõistavad kooli väärtusi. Näiteks koguvad koolid tagasisidet mitmesuguste (rühma)tegevuste abil väärtusmatkadest fotojahini:

Liikumisõpetuse tundides keskenduti kooli väärtustele läbi „Fotojahi“ meetodi, kus kooli vä̈rtused pü̈üt pildile ópilaste silme läbi. Iga tehtud pildi juures oli ka arutelu selle kohta, kuidas ópilased ise väärtusi mõtestavad. (2019 väike linnakool 2)

Koolid ei keskendu seega üksnes deklareeritud väärtuste mõtestamisele, vaid tähelepanu pööratakse ka tegelike väärtuste ilmnemisele. Õpetajad suunavad õpilasi värrtusi teadlikult märkama ja nende üle arutlema.

Samuti kaasavad koolid õpilasi kooli arendustegevustesse näiteks aruteluformaatides osalemise kaudu:

Õppekeskkonna arendusprotsessi oleme kaasanud ka õpilased - nt oleme ópilaste mõtete ja soovide kaardistamiseks viinud koolis läbi arvamusfestivali ning korraldanud mõttetalguid nt õpilasesinduse ja koorikooli õpilaste seas. (2019 suur linnakool 1)

Õpilastega arutlemiseks kasutatakse koolides mitmesuguseid formaate, mis on alguse saanud muu hulgas õpilaste endi algatustest ning mis oma olemuselt sarnanevad nende formaatidega, mida kasutatakse lapsevanematega arutlemiseks. Nii õpilaste kui ka lastevanemate kaasamiseks kasutatakse uudseid meetodeid (õpilaste puhul ilmneb, et õpilaste kaasamine arendustegevustesse on veel üsna uus lähenemine) ja püütakse leida tõhusaid lahendusi. Koolid toovad välja, et õpilaste arvamuste ning ettepanekutega arvestatakse kooli igapäevaelus.

Teise olulise õpilaste kaasamise formaadina näevad eneseanalüüsi kirjutajad õpilasesindust, millel nähakse olevast kaks peamist rolli: ürituste korraldamine ja kooli arendustegevust puudutavates protsessides osalemine.

Õpilasesindus ja tugiõpilasring TORE tegutsevad oma tegevuste ja sündmustega just sihilikult selles suunas, et nii korraldajad kui osalejad oleksid ópilased ise. (2016 suur maakool D)

Õpilasesindus arutab läbi kooli jaoks olulised korrad ja teeb ettepanekud. (2010 väike maakool 1) 
Koolid toovad oma analüüsides välja näiteid rakendatud ettepanekutest, näiteks huviringide avamise, tunni pikkuse kohandamise ning aktiivse vahetunni kohta. Selle põhjal saab öelda, et koolid kaasavad õpilasi sisuliselt, viies neilt saadud ettepanekud jõudumööda ellu.

Väljundina näevad koolid õpilaste kaasamist koolikeskkonna kujundamisse, mis tähendab valdavalt seda, et koolimaja seintel eksponeeritakse õpilaste kunstitöid, ent leidub ka teistsuguseid lähenemisi:

Õpilasi kaasatakse koolielu ja koolikeskkonda kujundavate atribuutide või kujunduselementide ideekonkursi kaudu. (2016 väike linnakool 2)

Eneseanalüüsidest nähtub, et õpilased saavad osaleda keskkonna kujundamises, kuid näiteid õpilaste endi algatustest on pigem vähem ja need on enamasti seotud loovtöödega. Samas peavad eneseanalüüsi kirjutajad õpilaste kaasamist keskkonna kujundamisesse oluliseks ja ühe põhjusena tuuakse välja asjaolu, et oma loodud keskkonda hoitakse meelsamini.

Eraldi toovad koolid keskkonna puhul välja õpilaste kaasamise väärtuste kommunikeerimisse:

Oleme öpilastega väärtused koos läbi arutanud, ópilased on klassides nende kohta ka postrid kujundanud, kus on välja toodud info, kuidas just konkreetse klassi õpilased väärtusi mõistavad. (2019 suur linnakool 2)

Meie koolis on kujundatud stend „Väärtuste puu“ [...], mille jaoks õpilased on pannud kirja nende jaoks olulised vä̈rtuseid tähistavad sõnad. (2016 suur maakool 1)

Peale õpilaste kaasatuse toetab selline väärtuste kommunikeerimine ka otseselt teadlikku väärtuskasvatust ja annab aluse iseloomukasvatuse rakendumisele (Berkowitz, 2002). Tulemustest selgus, et koolid panevad rõhku õpilaste eneserefleksiooni ja eneseanalüüsi toetamisele ja tegemisele, andes õpilastele eakohaseid võimalusi oma õpitee suunamiseks. Siia alla kuuluvad näiteks tegevused, millega koolid toetavad õpilaste vastutuse kujunemist valikute tegemise võimaluse varal:

Õpilased, kes käivad koolist kaugemal ringitegevustes, siis kokkuleppel vanemaga oleme lubanud ópilasel puududa viimasest tunnist ning vajaliku óppematerjali omandada iseseisvalt. (2019 väike maakool 4).

[...] hilinemiste iseseisev märkimine õpetajate toas olevale stendile. Õpilane, kes hommikul hilineb, tuleb kirjutab ise oma nime tabelisse. (2016 väike linnakool 3) 
Need näited on koolide eneseanalüüsides seostatud õpilase individuaalsuse väljaselgitamise ning arvestamisega. Eneseanalüüsides ei pöörata sellistele tegevustele väga suurt tähelepanu ja neid ei analüüsita põhjalikumalt, kuid oma olulisusega tõusevad nad siiski esile.

Õpilaste eneseanalüüsi oskust ja selle arendamist peetakse väga oluliseks. Seejuures jagunevad näited õpilaste eneseanalüüsist selgelt kaheks: ühelt poolt eneseanalüüs, mis keskendub õpitulemustele:

\section{[...] hinnati enesehinnangulehel oma öpiväljundite saavutamist [...] (2019 väike maakool 7)}

Teiselt poolt eristuvad selgelt näited õpilaste eneseanalüüsist, mis keskenduvad väärtustele:

[...] tegime kirjaliku eneseanalüüsi „Kas ma olen järginud kooli põhiväärtusi?" Iga ôpilane pidi enda kohta anonüümselt kirjutama, kas ja kuidas on temal lood kooli vä̈rtuste järgimisega. Kui ópilane leidis, et pole alati aus olnud, pidi tooma ka näiteid. (2010 väike maakool 2)

Valimisse kuulunud koolid toetavad väärtuskasvatuses olulist refleksiooni, tuues välja näiteid õpilaste eneseanalüüsidest valdavalt õppeaasta lõpus, aga olenevalt temaatikast ka õppeaasta kestel. Tagasisidet saavad õpilased oma eneseanalüüsidele peamiselt arenguvestluste käigus. Koolid tõid analüüsides välja palju väärtuskasvatust toetavaid tegevusi, milles õpilased on aktiivsem pool. Siinkohal tõusevad esile mängulised ja loomingulised lähenemised, õpilastele suunatud väärtustel põhinevad arutelud, ürituste korraldamine ja keskkonna kujundamine.

\section{Tegevuste tulemuslikkuse hindamiseks kasutatavad meetodid}

Peamiselt nimetavad koolid tulemuslikkuse näitaja ning analüüsi alusena rahulolu-uuringuid ning teisi eri eesmärkidel koostatud küsitlusi, mida saab jagada kolmeks: väljastpoolt kooli tulevad küsitlused (näiteks Innove, KiVa ja Liikuma Kutsuv Kool), kooli personali (enamasti juhtkonna) koostatud küsitlused ja õpilaste koostatud küsitlused (loov- ja uurimistööde käigus):

Õpilasuurimus õpilaste käitumisest [seoses kooli ühe põhiväärtuse ilmnemisega]. (2016 suur linnakool 2)

[...] esitati õpetajate rahulolu-uuringus küsimus: Kuidas tunnetad $X$ aluseks olevate väärtuste ilmnemist igapäevases töös. (2016 väike linnakool 4) 
Kuigi rahulolu-uuringutes esitatakse küsimusi ka kooli väärtuste ja nende ilmnemise kohta, on selliseid küsimusi pigem vähe ja toetudes valimisse kuulunud andmestiku analüüsile, saab öelda, et väärtuste ilmnemise uurimiseks kasutatakse teistsuguseid, pigem loomingulisi meetodeid (eespool kirjeldatud õpetajate töörühm, fotojaht, aga ka uutele vanematele esitatav küsimus koolivaliku kohta).

Koolid nimetavad tulemuslikkuse näitajana ka poolte vestlusi. Peamiselt kuuluvad siia alla arenguvestlused õpilaste ja lastevanematega ning õpetajatega:

[...] arenguvestlustes toovad välja klassijuhatajate hinnangul peamiste positiivsete külgedena kooli kohta sõbralikud suhted, avatud õpetajad, juhtkonna ja hea koolikliima. (2016 suur linnakool 2)

Samuti peavad koolid oluliseks tagasisideks õpilastega peetud vestlusi, mis võivad toimuda spontaanselt või planeeritult näiteks klassijuhatajatunnis või planeeritult teistsuguses formaadis:

Õpilased märkavad rohkem olukordi, kus nad peaksid teistmoodi tegutsema või käituma (annavad tagasisidet, muudavad käitumist jne). (2019 väike linnakool 2)

Näiteid on ka kooli pidajaga toimuvatest aruteludest:

Valla aruteluseminari soovituste ja [...] juhtkonna läbiviidud SWOT [...] analüusi kui sisendi kaudu hinnati óppekasvatusprotsessi hetkeseisu ja leiti järgmised kitsaskohad [...] (2019 suur maakool 2)

Vestlused ja nende kokkuvõtted annavad juhtkonnale tagasisidet tugevuste ning võimalike arengukohtade asjus. Mõnel juhul peetakse vestlusi küsitlustest olulisemaks. Kui enamasti jäävad sellised vestlused eneseanalüüsides põhjalikumalt lahti kirjutamata ja ei selgu näiteks nende struktuur, siis ühe kooli puhul tehti õpilasesindusega fookusgrupi intervjuu eesmärgiga saada õpilastelt tagasisidet kooli ühe põhiväärtuse ilmnemise kohta. Õpilastelt küsiti, kuidas nad seda väärtust mõistavad, missugused head näited seda toetavad, mis jääb puudu ja mis peaks olema teisiti.

Koolide eneseanalüüsidest nähtub, et heaks indikaatoriks sellele, kas kasutatavad meetodid on tõhusad, peetakse ka mitmesuguseid tulemusi (konkursside ja tasemetööde tulemused, asukoht koolide pingereas, üritustel osalemine, probleemvestluste vähenemine).

Riigieksamite, põhikooli lõpueksamite ja tasemetööde tulemuste näitajad on põhinäitajateks. (2019 suur linnakool 3) 
Tulemuslikkust saab hinnata nt. probleemvestluste hulga (vähenemise) põhjal. (2016 väike maakool 1).

Ilmneb, et peamiselt esitatakse tulemusi statistilise analüüsi abil. Seejuures pööratakse rohkem tähelepanu arvulistele näitajatele ning vähem tähelepanu põhjuslike seoste analüüsile. Lisaks kasutavad koolid dokumentide analüüsi, mis annab tervikliku ülevaate koolis toimuvast, aga võimaldab välja selgitada ka tegelikke väärtusi:

Läbi töötati nii klassijuhatajate kui aineõpetajate tööplaanid, kooli huvijuhi tegevuskavad, kooli traditsioonilised üritused, seni esile kerkinud uuenduslikud ideed ja tugipersonali tegevus. (2010 suur linnakool A)

Dokumentide analüüsi kasutavad nii juhid kui ka õpetajad, et võrrelda püstitatud eesmärke ja tegelikult saavutatut, samas on just selle meetodi puhul kõige vähem näiteid järeldustest ning nendest tulenevatest muudatustest.

Võrdlemisi vähe, kuid siiski mõnevõrra kasutavad juhid ja õpetajad meetodite tõhususe hindamiseks ning tagasiside saamiseks tunni- või keskkonnavaatlust. Seejuures on levinumaks vormiks tunnivaatlus ja vähem on näiteid teistsuguse fookusega vaatlusest.

Vaatlused annavad palju informatsiooni, kuidas reegleid ja kokkuleppeid täidetakse. Seda saab teha nii kooli personal kui ópilased. [...] kutsusime ópilasi üles märkama head kui ka häirivat koolielus. Tulemusi arutasime nii ópetajatega kui ópilasesindusega. (2019 väike makkool 6)

Vaatluste puhul ilmneb korduvalt, et vaatlusi peavad koolid oluliseks tagasisidestamise ning tulemuslikkuse hindamise meetodiks, ent samal ajal tunnistatakse, et vaatlusi (eelkõige õpetaja-õpetaja tasandil) tehakse vähe ja neid tuleks teha rohkem.

Valimisse kuulunud eneseanalüüsidest ilmnes, et väärtuskasvatust toetavate tegevuste tulemuslikkust analüüsivad koolid mitmesuguste meetodite abil ja siin on näha ajalist muutust. 2010. aasta eneseanalüüsides on võrreldes 2016. ja 2019. aasta analüüsidega vähem näiteid tulemuslikkust hindavate meetodite kasutamisest. Iseloomulik on saadud tulemuste vähene analüüs ja saab öelda, et eneseanalüüsides kirjeldatud tegevusi ei seostata enamasti otseselt tulemuslikkuse hindamisega. 


\section{Diskussioon}

Üldhariduskoolide koostatud 39 eneseanalüüsi kvalitatiivse sisuanalüüsi tulemused näitavad, et koolide välja toodud väärtuskasvatust toetavates tegevustes tõusevad peamiste teemadena esile õpetaja ja õpilane. Koolid kasutavad oma tegevuse tulemuslikkuse hindamiseks mitmekesiseid sotsiaalteaduslikke meetodeid, kuid kitsaskohaks on tulemuste tõlgendamine. Näiteks Hargreaves ja Shirley (2009) soovitavad andmete kogumisel ning analüüsimisel kasutada teiste koolide abi, tuues eeskujuks Soome koolijuhid, kes üksteist sarnaste eesmärkide saavutamisel toetavad. Samalaadseid algatusi ilmneb ka Eestis, näiteks on olemas alustava koolijuhi arenguprogramm (i.a) ning hea kooli kriitilised sõbrad (i.a).

Väärtustel põhinevate arutelude korraldamist klassijuhatajana saab liigitada kui ratsionalistliku kõlbluskasvatuse alla kuuluvat. Klassijuhataja rolli olulisust on ka kirjanduses rõhutatud, näiteks tõid Bonny jt (2000) välja, et see mõjutab õpilase sidet kooliga. Ratsionalistliku kõlbluskasvatuse alla kuuluvaks saab lugeda ka õpetajate enesearengut toetava refleksiooni, samuti kooli väärtuste mõtestamise.

Eneseanalüüside koostajate hinnangul olulisel kohal olev õpetajate isiklik eeskuju, mis ilmneb ka õpetajate omavahelises koostöös, kuulub kirjanduse järgi iseloomukasvatuse valdkonda. Õpetajate omavahelist koostööd peetakse oluliseks, sest see on eeskujuks, mille järgi saavad õpilased ise koostööd teha, mis omakorda on seotud klassi keskkonna tajuga (Solomon jt, 1996). Iseloomukasvatust toetab õpetajate kaasamine juhtimisprotsessidesse ning arendustegevustesse, sest aitab kujundada väärtustel põhinevat keskkonda, samal ajal kasutatakse ka siin õpetajate refleksiooni, mis kuulub ratsionalistliku kõlbluskasvatuse alla. Õpetajate refleksioonil oma uskumuste ja väärtuste üle on Suyatno jt (2019) sõnul oluline roll igapäevatöös ning see mõjutab õpetajate käitumist, mis omakorda mõjutab väärtuskasvatust toetavat keskkonda.

Ratsionalistliku kõlbluskasvatuse alla kuuluvad ka õpilastega seonduvad tegevused, mille keskmes on väärtuste mõistmine ja mõtestamine, vastuoluliste väärtuste märkamine ja õpilaste eneserefleksioon. Seevastu õpilaste kaasamisega arendustegevustesse ning koolikeskkonna kujundamisesse toetatakse iseloomukasvatust. Õpilased on kaasatud näiteks huviringide valiku tegemisse, mis suurendab õpilaste seotust kooliga ja on seega üks riskikäitumise kaitsefaktoreid (Resnick jt, 1997).

Sellest lähtuvalt saab öelda, et Eesti üldhariduskoolides on levinud integreeriv eetiline kasvatus, mis Narvaezi (2006) järgi seob tervikuks reflekteeriva arutlusvõime arendamise ja teatud iseloomujoontele keskendumise.

Kui väärtuskasvatuse toetamine õpetajate poolt näib olevat suuresti midagi sellist, mida õpetajad teevad paralleelselt igapäevase õppetööga, ja jääb 
küsimus, mil määral on nad selle tegevuse juures väärtuskasvatusest teadlikud, siis õpilaste teadlikkuse tõstmine näib olevat õpetajate ülesanne. Kui näiteks suunatud väärtuste mõtestamine õpetajate poolt on pigem seotud uue arengukava perioodi algusega, siis õpilased teevad seda õpetajate suunamisel pidevalt. Kummatigi ilmneb siin vastuolu: õpetajad toetavad õpilaste teadlikkust ilma, et nad ise seda samal määral kogeksid, teisalt selgub, et otseselt õppetöösse integreeritud teadlikule väärtuskasvatusele ei pöörata nii palju tähelepanu kui õppetööst eraldiseisvale väärtuskasvatusele. Väärtuskasvatus õppetöös näib olevat igapäevase töö loomulik osa.

Samal ajal toovad koolid oma analüüsides välja näiteid kas konkreetse õpetaja kohta või organisatsiooni üldistades ning seega ei selgu kooli tervikpilt, mis arvestaks iga õpetaja vastutust ning seda, kuidas ta oma rolli täidab. Koolide analüüsides on suurem rõhuasetus tegevuste kirjeldusel ja vähem pööratakse tähelepanu sellele, kes teeb ning kelle vastutus see on. Seetõttu tekkis näidete põhjal üldisem, organisatsiooni tasandi teema, mille sisulise poole lahtimõtestamine - ehk mida koolid näevad organisatsiooni laiema vastutusena võiks olla uue uurimuse ülesanne.

Kuigi eneseanalüüsides kirjutatakse, et väärtuskasvatuse võtmeisik on õpetaja, nähtub analüüsist, et fookus on suunatud õpilastele, ja õpetaja tasandist selgemalt ilmneb siin õpilaste kaasatuse määr - õpilastele antakse sõna, neid kuulatakse ära ja nende ettepanekutega arvestatakse. See toetab haridusvisiooni prioriteete (Aarna jt, 2011; Sutrop, Lauristin, Loogma, \& Eamets, 2019), eriti aga lähenemist õpilasele kui tervikule, sest õpilast kaasates toetatakse õppija individuaalsust ja tema pädevusi.

Siinse uurimuse põhjal saab öelda, et Eesti koolides on levinud integreeriv eetiline kasvatus ning kasutatakse mitmesuguseid väärtuskasvatust toetavaid tegevusi ja nende tulemuslikkuse hindamiseks kasutatakse mitmesuguseid sotsiaalteaduslikke meetodeid. Kuivõrd tajuvad õpetajad oma vastutust väärtuskasvatuse võtmeisikuna ning kas ja kuidas toetavad seda koolijuhid? Kas ja mil määral võtavad õpilased vastu neile antud vastutust? Need on küsimused, millele tuleb vastused leida järgmistes uurimustes näiteks koolijuhtide ja õpetajate intervjueerimise teel. Samas maksab nende küsimuste peale mõelda juba praegu kooli igapäevaelu korraldades nii koolidel endil kui ka hariduselu korraldavatel asutustel. Kuigi siinse uurimuse valimist lähtuvad tulemusi ei saa üldistada kõikidele koolidele, võib ühe soovitusena siiski öelda, et peale üldiste väärtuskasvatuslike põhimõtete kokkuleppimise ja rakendamise on tulemuslikku värrtuskasvatust silmas pidades tähtis tõsta õpetajate ja kogu koolipere teadlikkust väärtustest ja nende mõjust ning kokku leppida iga töötaja (siin kontekstis eelkõige iga üksiku õpetaja) vastutus ja ülesanded väärtuskasvatuse elluviimisel. 


\section{Tänusõnad}

Artikli valmimist on toetanud Euroopa Liidu Regionaalarengu Fond (Eestiuuringute tippkeskus), ning see on seotud Eesti Haridus- ja Teadusministeeriumi uurimisprojektiga IUT20-5 ning Haridus- ja Teadusministeeriumi riikliku programmi „Eesti ühiskonna värrtusarendus 2009-2013“ jätkuprogrammiga 2015-2020.

Täname professor Halliki Harro-Loiti ning professor Margit Sutropit nende põhjalike tähelepanekute eest! Samuti täname Tiina Kirssi inglise keele toimetamise eest ning Mari-Liis Nummertit, Triin Paaverit, Õnne Allajet, Marten Juurikut ja Laura Lilles-Heinsarit ja teisi kolleege Tartu Ülikooli eetikakeskusest, kes olid meile artikli kirjutamisel abiks.

\section{Kasutatud kirjandus}

Aarna, O., Annus, T., Heidmets, M., Lauristin, M., Loogma, K., Rebane, E., Ruus, V., Sutrop, M., Vernik-Tuubel, E.-M. (2011). Eesti hariduse viis väljakutset. Eesti haridusstrateegia 2012-2020 taustamaterjal. Külastatud aadressil https://www.haridusfoorum.ee/images/stories/haridusstrateegia/eesti-haridusstrateegia-2012-2020-taustamaterjal.pdf

Alustava koolijuhi arenguprogramm. (i.a). Külastatud aadressil https://www.hm.ee/ et/tegevused/opetaja-ja-koolijuht/alustavate-koolijuhtide-arenguprogramm

Bergdahl, L., \& Langmann, E. (2018). Time for values: Responding educationally to the call from the past. Studies in Philosophy and Education, 37(4), 367-382. https://doi.org/10.1007/s11217-017-9591-2

Berkowitz, M. W. (2002). The science of character education. W. Damon (Ed.), Bringing in a new era in character education (pp. 43-63). Stanford California: Hoover Institution Press.

Berkowitz, M. W. (2009). Teaduspõhine iseloomukasvatus. M. Põder, M. Sutrop, \& P. Valk (Eds.), Väärtused, iseloom ja kool. Väärtuskasvatuse lugemik (pp. 193213). Tartu: Eesti Keele Sihtasutus.

Berkowitz, M. W., \& Bier, M. (2009). Iseloomukasvatuse interpersonaalsed juured. M. Põder, M. Sutrop, \& P. Valk (Eds.), Väärtused, iseloom ja kool. Väärtuskasvatuse lugemik (pp. 289-311). Tartu: Eesti Keele Sihtasutus.

Berkowitz, M. W., \& Bustamante, A. (2013). Using research to set priorities for character education in schools: A global perspective. KEDI Journal of Educational Policy, 7-20.

Bonny, A. E., Britto, M. T., Klostermann, B. K., Hornung, R. W., \& Slap, G. B. (2000). School disconnectedness: Identifying adolescents at risk. Pediatrics, 106(5 I), 1017-1021. https://doi.org/10.1542/peds.106.5.1017

Brighouse, H. (2006). On education. London and New York: Routledge.

Chazan, B. (1985). Moral education as values clarification. T. C. Press (Ed.), Contemporary approaches to moral education (pp. 45-67). New York.

Eesti ühiskonna vä̈rtusarendus 2009-2013. (s.a). Külastatud aadressil https://www.eetika.ee/et/vaartusarendus/vaartusprogramm-2009-2013-taust 
Ezzy, D. (2002). Qualitative analysis, practice and innovation. London: Routledge.

Fadel, C., Bialik, M., \& Trilling, B. (2015). Four-dimensional education: the competencies learners need to succeed. Boston: Center for Curriculum Redesign.

Gutman, A. (1987). Democratic education. Princeton, New Jersey: Princeton University Press.

Hargreaves, A. \& Shirley, L. D. (2009). The fourth way: The inspiring future for educational change. The United States of America: Corwin Press.

Harro-Loit, H., Blaubrük, A.-L., Hallast, P., Harro, H., Jung, N., Korts, K., Schihalejev, O., Siivelt, P. (2011). Väärtusarenduse analüüs - miks ja kuidas? Tartu: Eesti Keele Sihtasutus.

Haydon, G. (2006). Values education: Teacher as transmitter of values? G. Haydon (Ed.), Values in education. London; New York: Continuum International Publishing Group.

Hea kooli ja hea lasteaia tunnustamine. (2020). Külastatud aadressil https://www.eetika.ee/et/hea-kool/hea-kooli-tunnustamine

Hea kooli kriitilised sõbrad (s.a). Külastatud aadressil https://www.eetika.ee/et/hea-kool-lasteaed/kriitiline-sober

Howes, C., Matheson, C. C., \& Hamilton, C. E. (1994). Maternal, teacher, and child care history correlates of children's relationships with peers. Child Development, 65(1), 264-273. https://doi.org/10.2307/1131380

Howes, C., \& Smith, E. W. (1995). Relations among child care quality, teacher behavior, children's play activities, emotional security, and cognitive activity in child care. Early Childhood Research Quarterly, 10(4), 381-404. https://doi.org/10.1016/0885-2006(95)90013-6

Jeynes, W. H. (2019). A meta-analysis on the relationship between character education and student achievement and behavioral outcomes. Education and Urban Society, 51(1), 33-71. https://doi.org/10.1177/0013124517747681

Kirschenbaum, H. (1977). Clarifying Values Clarification: Some Theoretical Issues. Advanced Values Clarification (pp. 7-16). La Jolla, California: University Associated Press.

Kirschenbaum, H. (2009). Väärtuste selitamise selgitus: mõned teoreetilised probleemid. M. Põder, M. Sutrop, \& P. Valk (Eds.), Väärtused, iseloom ja kool. Väärtuskasvatuse lugemik (pp. 123-134). Tartu: Eesti Keele Sihtasutus.

Kirschenbaum, H. (2013). Values clarification in counseling and psychotherapy. Practical strategies for individuals and group settings. New York: Oxford University Press.

Kohlberg, L. (1981). The philosophy of moral development: Moral stages and the idea of justice. Essays on moral development (Vol. 1). San Francisco: Harper \& Row.

Krek, J., \& Zabel, B. (2017). Why there is no education ethics without principles. Educational Philosophy and Theory, 49(3), 284-293. https://doi.org/10.1080/00131857.2016.1217188

Käger, M., Vollmer, M., Harjo, M., Pertšjonok, A., Gutman, K., Kaldur, K., Käsper, K., Grossthal, K., Rajaver, L., Meiorg, M. (2017). Inimõigused ja inimõiguste alusväärtused Eesti koolis ja hariduspoliitikas. Balti Uuringute Instituut, Eesti Inimõiguste Keskus.

Laherand, M-L. (2008). Kvalitatiivne uurimisviis. Tallinn: Infotrükk. 
McNeely, C. A., Nonnemaker, J. M., \& Blum, R. W. (2002). Promoting school connectedness: Evidence from the national longitudinal study of adolescent health. Journal of School Health, 72(4), 138-146. https://doi.org/10.1111/j.1746-1561.2002.tb06533.x

Narvaez, D. (2006). Integrative ethical education. M. Killen \& J. Smetana (Eds.), Handbook of moral development (pp. 703-732). London: Lawrence Erlbaum Associates, Inc, Publishers.

Pojman, L. P. (2005). Eetika. Õiget ja väära avastamas. Tallinn: Eesti Keele Sihtasutus.

Power, F. C., Higgins, A., \& Kohlberg, L. (1989). Critical assessments of contemporary psychology. Lawrence Kohlberg's approach to moral education. Columbia University Press.

Põder, M., Sutrop, M., \& Valk, P. (2009). Pööre teadmistekeskselt koolilt väärtustekesksele koolile. Sissejuhatus. Väärtused, iseloom ja kool. Väärtuskasvatuse lugemik (pp. 7-21). Tartu: Eesti Keele Sihtasutus.

Põhikooli riiklik õppekava. (2011). Külastatud aadressil https://www.riigiteataja.ee/akt/129082014020?leiaKehtiv

Raths, L., Harmin, M., \& Simon, S. (1978). Values and Teaching: Working with Values in the Classroom (2nd ed.). Columbus, Ohio: Charles E. Merrill.

Resnick, M. D., Bearman, P. S., Blum, R. W., Bauman, K. E., Harris, K. M., Jones, J., Tabor, J., Beuhring, T., Sieving, R. E., Shew, M., Ireland, M., Bearinger, L. H., Udry, J. R. (1997). Protecting adolescents from harm: Findings from the national longitudinal study on adolescent health. JAMA, 278(10), 832. https://doi.org/10.1001/jama.1997.03550100049038

Rokeach, M. (1975). Towards a philosophy of values education. J. Meyer, B. Burnham, \& J. Cholvat (Eds.), Values education: Theory, practice, problems, prospects. Waterloo, Ontario: Wilfrid Laurier University Press.

Rokeach, M. (1979). Understanding human values: individual and societal. New York: Free Press.

Ryan, A. M., \& Patrick, H. (2001). The classroom social environment and changes in adolescents' motivation and engagement during middle school. American Educational Research Journal, 38, 437-460. https://doi.org/10.3102/00028312038002437

Simon, S. B., Howe, L. W., \& Kirschenbaum, H. (1978). Values clarification. A handbook of practical strategies for teachers and students. Hart Publishing Company, Inc.

Simon, S. B., \& Olds, S. W. (1976). Helping your child learn right from wrong: a guide to values clarification. New York: Simon and Schuster.

Solomon, D, Watson, M. S., \& Battistich, V. A. (2001). Teaching and schooling effects on moral/prosocial development. V. Richardson (Ed.), Handbook of research on teaching (4th ed., pp. 566-603). Washington, D. C.: American Educational Research Association.

Solomon, Daniel, Battistich, V., Dong-Il, K. I. M., \& Watson, M. (1996). Teacher practices associated with students' sense of the classroom as a community. Social Psychology of Education, 1(3), 235-267. https://doi.org/10.1007/BF02339892

Sutrop, M. (Ed.). (2013). Väärtuspõhine kool. Eesti ja maailma kogemus. Tartu: Eesti Keele Sihtasutus.

Sutrop, M. (2015). Can values be taught? The myth of value-free education. Trames, 19(2), 189-202. https://doi.org/10.3176/tr.2015.2.06 
Sutrop, M. (2017). Sissejuhatuseks. Hea kooli mudelist. M. Sutrop, H. Toming, \& T. Kõnnussaar (Eds.), Hea kooli käsiraamat (pp. 9-15). Eesti Keele Sihtasutus.

Sutrop, M., \& Harro-Loit, H. (2013). Hea kooli mõõdupuud - miks ja kuidas? M. Sutrop (Ed.), Väärtuspõhine kool. Eesti ja maailma kogemus (pp. 216-246). Tartu: Eesti Keele Sihtasutus.

Sutrop, M., Lauristin, M., Loogma, K., \& Eamets, R. (2019). Ekspertrühmade tulevikuvisioonid ja ettepanekud Eesti haridus-, teadus-, noorte- ja keelevaldkonna arendamiseks aastatel 2021-2035.

Sutrop, M., Toming, H., \& Kõnnussaar, T. (Eds.). (2017). Hea kooli käsiraamat. Tartu: Eesti Keele Sihtasutus.

Suyatno, Pambudi, D. I., Mardati, A., Wantini, Nuraini, E., \& Yoyo. (2019). The education values of Indonesian teachers: Origin, importance, and its impact on their teaching. International Journal of Instruction, 12(3), 633-650. https://doi.org/10.29333/iji.2019.12338a

Volkmor, C. B., Pasanella, A. L., \& Raths, L. E. (1977). Values in the classroom. C.E. Merrill Pub. Co.

Wang, M. C., Haertel, G. D., \& Walberg, H. J. (1993). Toward a knowledge base for school learning. Review of Educational Research, 63(3), 249-294.

Wentzel, K. R. (2002). Are effective teachers like good parents? Teaching styles and student adjustment in early adolescence. Child Development, 73(1), 287-301.

Ounapuu, L. (2014). Kvalitatiivne ja kvantitatiivne uurimisviis sotsiaalteadustes. Tartu: Tartu Ülikool. 


\title{
Practices supporting values education and its assessment in Estonian schools
}

\author{
Mari-Liisa Parder ${ }^{1 a}$, Helen Hirsnik ${ }^{a}$ \\ ${ }^{a}$ Centre for Ethics, University of Tartu
}

\section{Summary}

\section{Introduction}

Education and the learning process are value-laden (e.g. Haydon, 2006; Sutrop, 2015). Therefore, the main question for education is not whether schools possess certain values, but rather how aware they are of them.

Values education approaches can be divided into three categories. 1) Rational moral education, which has its roots in universal ethical principles, focuses on reflexive discussion and educating the autonomous moral actor (e.g. Kohlberg, 1981; Power, Higgins, \& Kohlberg, 1989). One method used in this approach is values clarification (Kirschenbaum, 1977) which provides children a tool to become aware of their own values (Simon \& Olds, 1976). Values education has been criticised e.g. by Rokeach $(1975,1979)$ who considers it naive with respect to the moral and social context. However, Kirschenbaum (1977) states that values education has never been, or never will be value free. 2) Character education focuses on creating the conditions for moral education, concentrating on the development of virtues. Berkowitz (2002) names seven aspects affecting the success of character education in school: 1) how people treat children; 2) how important people treat other people in the presence of children; 3) the expectation of good character from everyone; 4) supporting positive character; 5) possibilities for practising good character; 6) possibilities for discussion on moral topics and 7) parents ' active and positive engagement with character education. 3) Narvaez (2006) offers a third possibility - integrative ethical education, which is a combination of both previously named approaches.

The aim of this research was to analyse activities that support values education and how Estonian schools assess its success.

Centre for Ethics, University of Tartu, Jakobi 2-329, Tartu, 51014 Estonia; mari-liisa.parder@ut.ee. 


\section{Study design and method}

The study concentrated on the 39 self-analyses of Estonian schools submitted to contests organised by the Centre for Ethics, University of Tartu. The names of schools were made anonymous by coding, which included the year the selfanalyses were written $(2010 ; 2016$ or 2019), the size of the school (large or small with a cut-off point of 350 students) and the location of the school (either in a city or rural area). In this article, examples from the self-analyses are presented together with the code of the school.

Self-analyses were examined using thematic content analysis. Because values education depends on certain agents (e.g. head of the school, teacher, student), main categories were derived from the literature so as to be agentoriented (Berkowitz, 2002; Berkowitz \& Bustamante, 2013; Haydon, 2006; Simon, Howe, \& Kirschenbaum, 1978; Sutrop, 2015). Overall 1924 segments were derived, including one main category for methods and seven for agents (school owner, headmaster, teacher, student, member of support system, other personnel and parents). The coded segments we analysed include examples of practices that answer the question: "How is it done?"

Two categories emerged from the perspective of agency: the teacher (240 segments) and the student (196 segments), and these were the main basis for the analysis. The student category includes segments that describe practices in which the student is the active participant.

However, there are several limitations to the study. Firstly, the self-analyses are written by schools which already consider values education a priority; secondly, the schools follow the framework of the Centre for Ethics at the University of Tartu in their self-analysis; thirdly, the results based on 39 selfanalyses cannot be generalised to other schools in Estonia. Nevertheless, the analysis does answer questions about how schools themselves give sense to practices supporting values education and what methods they use to assess the effect of these activities.

\section{Results}

The results show that practices supporting values education in Estonian schools are correlated with different agents; the two main agents emerging from self-analysis were the student and the teacher. Schools use a variety of methods (from questionnaires to interviews and document analysis) to assess the success of their activities, but they need more support in translating the results.

Teacher-related activities in the category of rational moral education approaches include class teachers' discussions with students about values. 
The role of class teachers is also emphasised in the literature, because it affects the students' relationship with the school, as Bonny et al. (2000) have shown. Reflection supporting teachers' professional development and discussions on how they understand school values can also be listed under rational moral education.

An example of character education in the self-assessments is teachers' setting of personal examples, such as in teacher collaboration which is also related to how students perceive the classroom environment (Solomon et al., 1996). Including teachers in management processes supports character education, because it helps create a values-oriented environment; however, teachers' reflection over these activities is better classified under rational moral education. Suyatno et al. (2019) stresses the importance of a teachers' reflection on their personal beliefs and values, since this is crucial in their everyday work life, affecting the behaviour of other teachers, which in turn affects the school environment's support for values education.

Practices related to students that focus on understanding and giving sense to values, as well as noticing conflicting values can mostly be categorised under rational moral education. Activities related to the inclusion of students in management processes and developing a values-oriented environment can be classified as character education. Inclusion of students in the choice of hobby groups increases their engagement with schools, which is considered one of the protective factors in risk behaviour (Resnick et al., 1997).

While values education of teachers takes place in parallel with their everyday work, and one might question the extent of their immediate awareness of the process, values education aimed towards students and developing their awareness is one of a teachers' acknowledged tasks. This highlights the contradiction of teachers' supporting students' values education without experiencing this on the same level.

It has to be noted that schools have presented their examples either from the perspective of the teacher or the overall organisation, which neither gives a full picture of the school, nor does it provide a detailed assessment of every teachers' responsibility and role performance. In self-analyses, schools emphasise descriptions of activities and pay less attention to who does what or the distribution of responsibility. Analysing what schools consider to be the organisation's tasks and how they understand notions related to this category may be a useful point of investigation in the future.

Although schools consider teachers to be the key to values education, our content analysis shows that the actual focus is on students, whose rate of involvement is higher - they are given space to speak; they are listened to; their proposals are taken into account. This supports the idea of the student as 
a whole as stated in the Estonian educational strategy and educational vision 2035 (Aarna et al., 2011; Sutrop, Lauristin, Loogma \& Eamets, 2019); students' individuality and their competencies are supported by involving them in decision-making.

Therefore, it can be concluded from our research that integrative ethical education, which according to Narvaez (2006) combines developing reflexive reasoning with focusing on certain character traits, has spread to Estonian schools. A range of different practices are used to support values education, the success of which is being evaluated by different social science methods. How do teachers perceive their role as values educators and how it is supported by headmasters? Whether or to what extent do students take the responsibility offered to them? These are questions to be examined in future research.

Keywords: values education, values clarification, aims of education 